University of Nebraska - Lincoln

DigitalCommons@University of Nebraska - Lincoln

\title{
Contribution of Postmortem Muscle Biochemistry to the Delivery of Consistent Meat Quality with Particular Focus on the Calpain System
}

\author{
M. Koohmaraie \\ USDA-ARS, koohmaraie@email.marc.usda.gov
}

G. H. Geesink

CCL B.V.

Follow this and additional works at: https://digitalcommons.unl.edu/hruskareports

Koohmaraie, M. and Geesink, G. H., "Contribution of Postmortem Muscle Biochemistry to the Delivery of Consistent Meat Quality with Particular Focus on the Calpain System" (2006). Roman L. Hruska U.S. Meat Animal Research Center. 244.

https://digitalcommons.unl.edu/hruskareports/244

This Article is brought to you for free and open access by the U.S. Department of Agriculture: Agricultural Research Service, Lincoln, Nebraska at DigitalCommons@University of Nebraska - Lincoln. It has been accepted for inclusion in Roman L. Hruska U.S. Meat Animal Research Center by an authorized administrator of DigitalCommons@University of Nebraska - Lincoln. 


\title{
Contribution of postmortem muscle biochemistry to the delivery of consistent meat quality with particular focus on the calpain system
}

\author{
M. Koohmaraie ${ }^{a, *}$, G.H. Geesink ${ }^{b}$ \\ ${ }^{a}$ Roman L. Hruska US Meat Animal Research Center, USDA-ARS, P.O. Box 166 - Spur 18D, Clay Center, NE 68933-0166, USA \\ ${ }^{\mathrm{b}}$ CCL B.V., Veghel, NL-5462, The Netherlands
}

Received 14 February 2006; received in revised form 28 April 2006; accepted 28 April 2006

\begin{abstract}
Tenderness has been repeatedly reported as the most important quality aspect of meat. However, a number of studies have shown that a significant portion of retail meat can be considered tough. As a consequence, a significant consumer segment is willing to pay a premium for guaranteed tender meat. However, apart from measuring the shear force, there is no reliable method to predict tenderness. Most of the branded meat programs therefore attempt to ensure eating quality by controlling some of the factors that affect tenderness.

Meat tenderness is determined by the amount and solubility of connective tissue, sarcomere shortening during rigor development, and postmortem proteolysis of myofibrillar and myofibrillar-associated proteins. Given the effect of postmortem proteolysis on the muscle ultrastructure, titin and desmin are likely key substrates that determine meat tenderness.

A large number of studies have shown that the calpain proteolytic system plays a central role in postmortem proteolysis and tenderization. In skeletal muscle, the calpain system consists of at least three proteases, $\mu$-calpain, m-calpain and calpain 3 , and an inhibitor of $\mu$ - and m-calpain, calpastatin. When activated by calcium, the calpains not only degrade subtrates, but also autolyze, leading to loss of activity. m-Calpain does not autolyze in postmortem muscle and is therefore not involved in postmortem tenderization. Results from a number of studies, including a study on calpain 3 knockout mice, have shown that calpain 3 is also not involved in postmortem proteolysis. However, a large number of studies, including a study on $\mu$-calpain knockout mice, have shown that $\mu$-calpain is largely, if not solely, responsible for postmortem tenderization. Research efforts in this area should, therefore, focus on elucidation of regulation of $\mu$ calpain activity in postmortem muscle. Discovering the mechanisms of $\mu$-calpain activity regulation and methods to promote $\mu$-calpain activity should have a dramatic effect on the ability of researchers to develop reliable methods to predict meat tenderness and on the meat industry to produce a consistently tender product.
\end{abstract}

Published by Elsevier Ltd.

Keywords: Meat; Tenderness; Postmortem; Calpain

\section{Introduction}

Multiple factors, including palatability, water-holding capacity, color, nutritional value and safety, determine meat quality. The importance of these traits varies depending on both the end product and the consumer profile. Flavor, juiciness and tenderness influence the palatability of meat. Among these traits, tenderness is ranked as most important (Miller, Carr, Ramsey, Crockett, \& Hoover,

\footnotetext{
* Corresponding author. Tel.: +1 402762 4109; fax: +1 4027624111.

E-mail address: koohmaraie@email.marc.usda.gov (M. Koohmaraie).
}

2001). An example of the importance of tenderness over flavor or juiciness is the tenderloin (psoas major). Although this cut is one of the least flavorful and least juicy cuts of meat, it is the most highly valued retail cut due to its supreme tenderness (Savell \& Shackelford, 1992). Further, it has been shown that consumers can distinguish between tough and tender meat (Huffman et al., 1996) and that they are willing to pay a premium for guaranteed tender meat (Boleman et al., 1997; Lusk, Fox, Schroeder, Mintert, \& Koohmaraie, 2001; Shackelford et al., 2001).

The objective of this review paper is to discuss (1) the importance and value of meat tenderness, (2) the effect of 
postmortem storage on muscle structure and tenderness, and (3) the role of the calpain proteolytic system in postmortem tenderization.

\section{The importance and value of meat tenderness}

Tenderness has been repeatedly reported as the most important quality attribute of meat (Huffman et al., 1996; Miller et al., 2001). However, surveys of beef packers, purveyors, restaurateurs and retailers indicate that tenderness is among the highest ranked quality concerns (Smith et al., 1995). This concern is warranted because a number of studies have shown that a significant proportion of retail meat cuts can be considered tough. In a large beef tenderness survey in 14 cities in the United States it was found that $10.7-61.8 \%$ of samples, depending on the retail cut, had a $68 \%$ chance of receiving panel tenderness scores of "slightly tough" or worse (Morgan et al., 1991). In a similar study it was found that $24 \%$ of US retail beef loin steaks were rated lower than "slightly tender" (George, Tatum, Belk, \& Smith, 1999). Results from a large study in New Zealand indicated that toughness problems are not limited to beef (Bickerstaffe, Bekhit, Robertson, Roberts, \& Geesink, 2001). For retail beef, lamb and pork midloin cuts $9.8 \%, 3.8 \%$ and $10.7 \%$, respectively, could be classified as "tough" or "very tough" (Bickerstaffe et al., 2001).

Traditional carcass grading systems are not effective at identifying meat tenderness variation. For instance, the US grading system uses marbling as a measure of quality. However, marbling explains at most $5 \%$ of the variation in beef tenderness (Wheeler, Cundiff, \& Koch, 1994). A grading system aimed at meat quality was developed by Meat Standards Australia (Polkinghorne et al., 1999). Based on critical control points for tenderness, juiciness, flavor and overall satisfaction, from production to processing and consumption, different cuts are graded "unsatisfactory" (no grade), "good everyday" (3 star), "better than everyday" (4 star) or "premium quality" (5 star). However, although this system works to reduce the probability that steaks are of unsatisfactory quality, $71 \%$ of striploins of "no grade" carcasses were judged acceptable by consumers, whereas $11 \%$ of striploins of graded carcasses were deemed unacceptable (Thompson, Polkinghorne, Watson, Gee, \& Murrison, 1999).

A large amount of effort has been devoted to the development of systems to classify carcasses according to tenderness. These include visible and near-infrared spectroscopy (Byrne, Downey, Troy, \& Buckley, 1998; Park, Chen, Hruschka, Shackelford, \& Koohmaraie, 1998; Shackelford, Wheeler, \& Koohmaraie, 2004, 2005), image texture analysis (Li \& Shatadal, 2001), image analysis using BeefCam (Belk et al., 2000; Vote, Belk, Tatum, Scanga, \& Smith, 2003), a combination of colorimeter, marbling and hump height traits (Wulf \& Page, 2000) or measurement of longissimus slice shear force (Shackelford, Wheeler, \& Koohmaraie, 1999). A direct comparison between the latter three methods indicated that only slice shear force accurately identified tender beef (Wheeler et al., 2002). Furthermore, accurately segregating carcasses based on longissimus tenderness also sorts other muscles for tenderness (Wheeler, Shackelford, \& Koohmaraie, 2000a; Wheeler et al., 2002). However, it appears that the industry is reluctant to implement slice shear force measurement because it is perceived as too costly (Wheeler et al., 2002).

The costs of automated classification using slice shear force were estimated at $\$ 4.35$ per carcass (Wheeler, Shackelford, \& Koohmaraie, 1999). The premium consumers are willing to pay should outweigh these costs. Boleman et al. (1997) reported that $94.6 \%$ of families $(n=42)$ chose steaks that were tender over intermediate and tough steaks, even though a $\$ 1.10 / \mathrm{kg}$ price difference was placed between each category. Shackelford et al. (2001) reported that 50\% of consumers $(n=1,036)$ were willing to pay $\$ 1.10 / \mathrm{kg}$ premium for the assurance of tenderness with the Tender Select concept. Lusk et al. (2001) found that $51 \%$ of participants $(n=86)$ in a survey were willing to pay an average premium of $\$ 4.05 / \mathrm{kg}$ for guaranteed tender beef. Recently, Feldkamp, Schroeder, and Lusk (2005) conducted a consumer evaluation study where participants were given a generic 12-oz. steak and asked to place bids to exchange it for a "guaranteed tender" steak. Consumers were willing to pay a $\$ 2.79 / \mathrm{kg}$ premium for "guaranteed tender" steak. From these numbers it appears that the benefits of a guaranteed tender beef concept may outweigh the costs. However, as mentioned by Shackelford et al. (2001), a number of factors need to be considered by retailers before implementing a guaranteed tender concept. These factors are: (1) how large does the premium for this product have to be to offset the costs of identifying, branding, and marketing the product line; (2) is there a sufficiently large enough market at the aforementioned premium price; (3) will sales of this branded product increase or decrease the sales of other higher-profit items; and (4) will there be a steady supply of the product line. From the studies mentioned above it appears that additional research is needed to determine the benefits and costs of a tenderness-certified program.

Approaches using spectroscopy, although not as accurate as slice shear force, are accurate enough to be useful to the industry and should be available commercially in the near future. Implementation of non-invasive approaches such as those using spectroscopy will be much less costly than slice shear force and should make it easier to develop a profitable marketing strategy for products with more consistent and/or superior tenderness.

\section{Growth of branded products and guaranteed tenderness products}

Because of the importance of eating quality to consumer satisfaction, there has been an explosion of branded meat products in the United States and probably worldwide. The first branded beef program in the United States was 
Certified Angus Beef (CAB) which was introduced in the late 1970 s. To date, CAB is a very successful beef promotion program. It is interesting to note that $\mathrm{CAB}$ does not include processes that are known to affect beef tenderness (e.g., 14 days' postmortem storage specification). Most of the branded beef programs that were introduced in the 1990s and 2000s attempt to ensure eating quality by controlling some of the factors that are known to affect beef tenderness (e.g., length of postmortem storage, electrical stimulation, tender-stretch, breed of cattle, etc.). We know of only one branded beef program in the United States that is based on actual measurement of tenderness. This level of interest by the industry to provide a highly acceptable product to consumers gives the researcher a unique opportunity to develop useful technology for the industry with a very high likelihood of implementation.

\section{The effect of postmortem storage on tenderness}

The three factors that determine meat tenderness are background toughness, the toughening phase and the tenderization phase. While the toughening and tenderization phases take place during the postmortem storage period, background toughness exists at the time of slaughter and does not change during the storage period. The effect of postmortem storage on tenderness is illustrated in Fig. 1.

The background toughness of meat is defined as "the resistance to shearing of the unshortened muscle" (Marsh \& Leet, 1966), and variation in the background toughness is due to the connective tissue component of muscle. In particular, the organization of the perimysium appears to affect the background toughness, since a general correlation between the perimysium and the tenderness of muscles has been found for both chicken and beef (Strandine, Koonz, \& Ramsbottom, 1949).

The toughening phase is caused by sarcomere shortening during rigor development (Koohmaraie, Doumit, \& Wheeler, 1996; Wheeler \& Koohmaraie, 1994). For beef, this process usually occurs within the first $24 \mathrm{~h}$ postmortem (Wheeler \& Koohmaraie, 1999). The relationship between

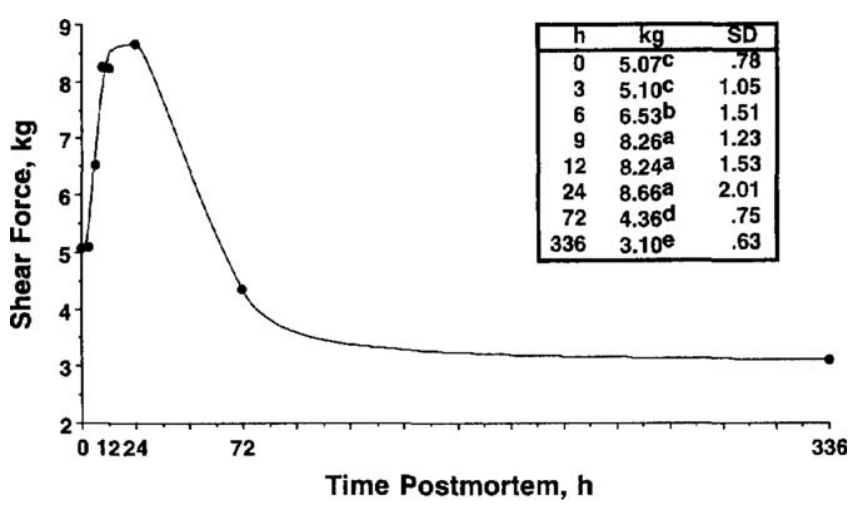

Fig. 1. Tenderness of ovine longissimus, measured by Warner-Bratzler shear force, at various times postmortem. Means without a common superscript differ $(P<0.05$; from Wheeler and Koohmaraie, 1994). sarcomere shortening and meat toughness was first reported by Locker (1960). Later it was shown that there is a strong negative relationship between sarcomere length and meat toughness when sarcomeres are shorter than $2 \mu \mathrm{m}$, and that the relationship is poorer at longer sarcomere lengths (Bouton, Harris, Shorthose, \& Baxter, 1973; Herring, Cassens, Suess, Brungardt, \& Briskey, 1967; Wheeler, Shackelford, \& Koohmaraie, 2000b).

While the toughening phase is similar in all carcasses under similar processing conditions, the tenderization phase is highly variable. There is a large variation in both the rate and extent of postmortem tenderization of meat, and this results in the inconsistency of meat tenderness found at the consumer level. It has been known for a long time that meat tenderness improves during cooler storage, and it was suggested almost a century ago that this is due to enzymatic activity (Hoagland, McBryde, \& Powick, 1917). It is now well established that postmortem proteolysis of myofibrillar and myofibrillar-associated proteins is responsible for this process.

\section{The effect of postmortem storage on muscle ultrastructure}

A variety of studies have shown that weakening of the myofibers is the key event in tenderization. The most consistently reported ultrastructural change associated with tenderization is breaks at the junction of the I band and Z-disk (Abbot, Pearson, Price, \& Hooper, 1977; Davey \& Dickson, 1970; Dutson, Pearson, \& Merkel, 1974; Ho, Stromer, Rouse, \& Robson, 1996; Taylor, Geesink, Thompson, Koohmaraie, \& Goll, 1995a). Because of the weakening of the myofibers, aged meat yields a higher proportion of smaller fragments upon homogenization than unaged meat. The myofibril fragmentation index (MFI), which is based on the fragmentation concept, has been used as an index for meat tenderness, as well as for postmortem tenderization (Davey \& Gilbert, 1969). Since then the MFI has been shown to be a predictor of meat tenderness in numerous studies (Olson, Parrish, Dayton, \& Goll, 1977; Taylor et al., 1995a; Whipple, Koohmaraie, Dikeman, \& Crouse, 1990a).

The proteins that are degraded during myofiber degradation are myofibrillar and cytoskeletal proteins, which include troponin-I, troponin-T, desmin, vinculin, meta-vinculin, dystrophin, nebulin and titin (see Robson et al., 1997 \& Taylor et al., 1995a, for reviews). Three major cytoskeletal structures are degraded when meat is tender: Z- to Zline attachments by intermediate filaments, Z- and M-line attachments to the sarcolemma by costameric proteins and the elastic filament protein titin (Taylor et al., 1995a). Z- to Z-line attachments are mostly composed of desmin. The importance of these attachments for meat tenderness is illustrated by the model of callipyge sheep, which show little postmortem tenderization (Koohmaraie, Shackelford, Wheeler, Lonergan, \& Doumit, 1995). For several weeks postmortem little degradation of desmin occurs (Geesink \& Koohmaraie, 1999b; Koohmaraie et al., 
1995), and the Z- to Z-line attachments remain largely intact (Fig. 2; Taylor \& Koohmaraie, 1998). Similarly, titin also remains largely intact for several weeks postmortem in muscles from callipyge sheep (Geesink \& Koohmaraie, 1999b). Detachment of the Z- and M-lines from the sarcolemma is probably not a limiting factor for tenderization. The detachment of these structures at 14 days postmortem was almost complete in both callipyge and control sheep, whereas a large difference in tenderness was observed (Taylor \& Koohmaraie, 1998). Thus, titin and desmin are likely key substrates that determine meat tenderness.

\section{What characteristics should a protease have to be considered as a candidate for causing postmortem tenderization?}

Three proteolytic systems present in muscle have been investigated for their possible role in postmortem proteolysis and tenderization: the calpain system, the lysosomal cathepsins and the multicatalytic proteinase complex (MCP). In addition to being endogenous in skeletal muscle, these proteolytic systems must fulfill two other requirements to consider them involved in postmortem proteolysis in meat (Goll et al., 1983; Koohmaraie, 1988). First, the proteases must have access to the substrates, and secondly, they must be able to reproduce the proteolysis pattern observed after postmortem storage of meat. Incubation of myofibrillar proteins with cathepsins results in different degradation patterns than those that occur during postmortem storage of muscle, and it is doubtful that cathep- sins are released from the lysosomes in postmortem muscle (Koohmaraie, 1988). A significant role for MCP can be excluded, since myofibrils are very poor substrates for this protease system (Koohmaraie, 1992). Moreover, the degradation pattern of myofibrillar proteins by $\mathrm{MCP}$ does not mimic the degradation pattern observed in postmortem muscle (Taylor et al., 1995b). This leaves the calpain system or potentially another, not yet investigated, proteolytic system responsible for postmortem proteolysis of key myofibrillar proteins and the resultant meat tenderization.

\section{7. $\mu$-Calpain is largely, if not solely, responsible for postmortem tenderization}

Calpains are calcium-activated proteases with an optimum activity at neutral $\mathrm{pH}$. In skeletal muscle, the calpain system consists of at least three proteases, $\mu$-calpain, $\mathrm{m}$-calpain and skeletal muscle-specific calpain, p94 or calpain 3, and an inhibitor of $\mu$-and m-calpain, calpastatin. Over the last decade multiple calpain-like genes have been identified, however little is known about the proteins encoded by these genes (Goll, Thompson, Li, Wei, \& Cong, 2003).

Both $\mu$ - and m-calpain are composed of two subunits with molecular weights of 28 and $80 \mathrm{kDa}$ (Dayton, Goll, Zeece, Robson, \& Reville, 1976; Dayton, Reville, Goll, \& Stromer, 1976; Dayton, Schollmeyer, Lepley, \& Cortés, 1981; Emori, Kawasaki, Imajoh, Kawashima, \& Suzuki, 1986). An important characteristic of $\mu$ - and m-calpain is that they undergo autolysis in the presence of calcium.
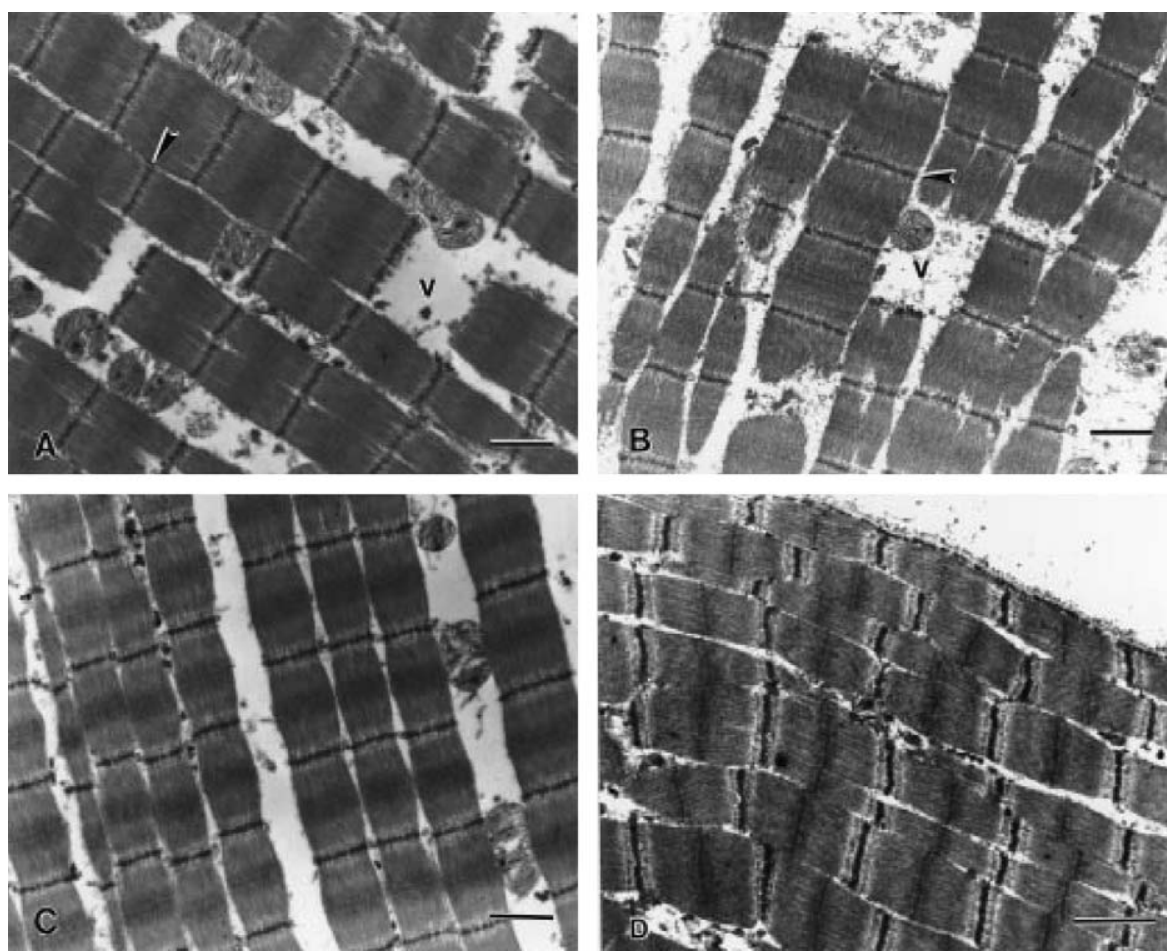

Fig. 2. Electron micrograph of myofibrils at 14 days after death. (A) and (B) show postmortem changes in normal lamb longissimus with I-band breaks (v), and loss of Z-line alignment. (C) and (D) show callipyge longissimus without I-band breaks. Bars represent $1 \mu \mathrm{m}$ (from Taylor and Koohmaraie, 1998). 
Autolysis reduces the $\mathrm{Ca}^{2+}$-requirement for half maximal activity of $\mu$ - and m-calpain (Dayton, 1982; Nagainis, Sathe, Goll, \& Edmunds, 1983; Suzuki et al., 1981; Suzuki, Tsuji, Kubota, Kimura, \& Imahori, 1981). Initial autolysis of the large subunit of $\mu$-calpain produces a $78-\mathrm{kDa}$ fragment followed by a 76-kDa fragment (Inomata, Kasai, Nakamura, \& Kawashima, 1988). Initial autolysis of the large subunit of m-calpain produces a $78-\mathrm{kDa}$ fragment only (Brown \& Crawford, 1993). Further autolysis of $\mu$ and $\mathrm{m}$-calpain leads to lower molecular weight fragments of the large subunit and loss of activity.

Calpain 3 is a single polypeptide of $94 \mathrm{kDa}$ with sequence homology to the large subunits of $\mu$ - and m-calpain (Sorimachi, Ishiura, \& Suzuki, 1989). Purification and characterization of calpain 3 has been extremely difficult for several reasons. Unlike $\mu$ - and m-calpain, calpain 3 can not be easily extracted from skeletal muscle due to its association with the myofibrillar protein, titin (Sorimachi et al., 1995). Expression of p94 in vitro is hampered by rapid autolysis of the enzyme at physiological levels of calcium, and furthermore, the autolysis is not affected by calpain inhibitors (Sorimachi et al., 1993).

Calpastatin is the endogenous specific inhibitor of $\mu$ and m-calpain (Maki et al., 1988). Several isoforms of this protein exist, but the predominant form in skeletal muscle contains four calpain-inhibiting domains (Lee et al., 1992). Calpastatin requires calcium to bind and inhibit calpains (Cottin, Vidalenc, \& Ducastaing, 1981; Imajoh \& Suzuki, 1985). Calpastatin is also a substrate for the calpains and can be degraded in the presence of calcium (Doumit \& Koohmaraie, 1999; Mellgren, Mericle, \& Lane, 1986). Degradation of calpastatin does not lead to complete loss of inhibitory activity, and even after extensive proteolysis some inhibitory activity remains (DeMartino, Wachendorfer, McGuire, \& Croall, 1988; Nakamura, Inomata, Imajoh, Suzuki, \& Kawashima, 1989).

For more detailed information regarding the calpain system, the reader is referred to the extensive review by Goll et al. (2003).

The evidence for the involvement of the calpain system in postmortem proteolysis and tenderization comes from a variety of studies (Fig. 3):

1. Incubation of myofibrils with calpains produces the same proteolytic pattern as observed in postmortem muscle (Geesink \& Koohmaraie, 1999a; Huff-Lonergan et al., 1996; Koohmaraie, Schollmeyer, \& Dutson, 1986).

2. Infusion or injection of muscles with calcium accelerates postmortem proteolysis and tenderization (Koohmaraie, Babiker, Schroeder, Merkel, \& Dutson, 1988; Koohmaraie, Whipple, \& Crouse, 1990; Wheeler, Crouse, \& Koohmaraie, 1992; Wheeler, Koohmaraie, \& Crouse, 1991), whereas infusion or injection of muscles with calpain inhibitors inhibits postmortem proteolysis and tenderization (Koohmaraie, 1990; Uytterhaegen, Claeys, \& Demeyer, 1994).
3. Differences in the rate of proteolysis and tenderization between species can be explained by the variation in calpastatin activity (Koohmaraie, Whipple, Kretchmar, Crouse, \& Mersmann, 1991a; Ouali \& Talmant, 1990).

4. Differences in the rate of postmortem proteolysis and tenderization between Bos taurus and Bos indicus cattle can be explained by the variation in calpastatin activity (Shackelford, Koohmaraie, Miller, Crouse, \& Reagan, 1991; Whipple et al., 1990b).

5. The toughening effect of treatment with $\beta$-agonists can be explained by an increase in calpastatin activity (Garssen, Geesink, Hoving-Bolink, \& Verplanke, 1995; Koohmaraie, Shackelford, Muggli-Cockett, \& Stone, 1991b).

6 . The greatly reduced rate and extent of postmortem proteolysis and tenderization in callipyge lamb can be attributed to elevated levels of calpastatin in these animals (Geesink \& Koohmaraie, 1999b; Koohmaraie et al., 1995).

7. Overexpression of calpastatin in transgenic mice results in a large reduction in postmortem proteolysis of muscle proteins (Kent, Spencer, \& Koohmaraie, 2004).

From the above-cited studies and others, it is clear that the calpain system plays an important role in postmortem proteolysis and tenderization. The remaining important question is, which of the calpains is responsible for postmortem proteolysis and tenderization?

An important characteristic of the calpains is that they autolyze once activated, ultimately leading to loss of activity (Dayton, 1982; Nagainis et al., 1983; Suzuki, Tsuji, Kubota, et al., 1981). In bovine and ovine postmortem muscle, the extractable activity of $\mu$-calpain declines, but the activity of m-calpain is remarkably stable (Ducastaing, Valin, Schollmeyer, \& Cross, 1985; Geesink \& Koohmaraie, 1999b; Kretchmar, Hathaway, Epley, \& Dayton, 1990; Veiseth, Shackelford, Wheeler, \& Koohmaraie, 2001). This observation led Koohmaraie, Seideman, Schollmeyer, Dutson, and Crouse (1987) to conclude that $\mu$-calpain, but not m-calpain, is responsible for postmortem tenderization.

Using Western blotting, it has been established that calpain 3 does autolyze in postmortem muscle (Anderson et al., 1998; Ilian, Bekhit, \& Bickerstaffe, 2004; Parr et al., 1999). In contrast with $\mu$-calpain and m-calpain, calpain 3 is not inhibited by calpastatin (Sorimachi et al., 1993). This observation excludes a major role of calpain 3 on postmortem proteolysis and tenderization, given the great influence of calpastatin activity on these events. This conclusion was further corroborated by results of a recent study showing that postmortem proteolysis is not affected in calpain 3 knockout mice (Geesink, Taylor, \& Koohmaraie, 2005).

The conclusion that $\mu$-calpain is responsible for postmortem proteolysis (Koohmaraie et al., 1987) was recently confirmed using $\mu$-calpain knockout mice (Geesink, Kuchay, Chishti, \& Koohmaraie, 2006). The results of this 


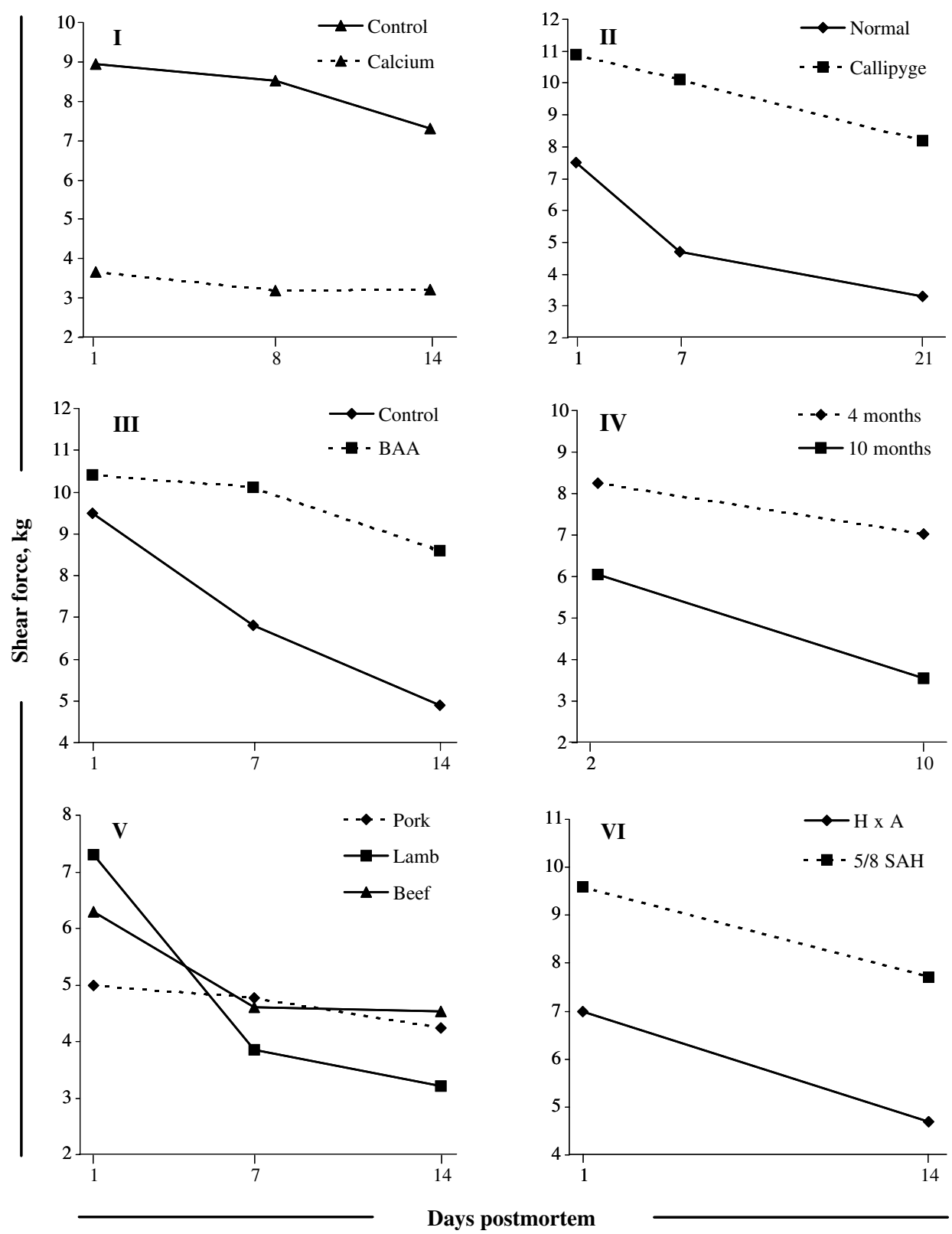

Fig. 3. Rate and extent of postmortem tenderization as affected by (I) $\mathrm{CaCl}_{2}$ injection (data from Wheeler et al., 1991); (II) callipyge phenotype (data from Koohmaraie et al., 1995); (III) $\beta$-adrenergic agonist treatment (data from Koohmaraie et al., 1991b); (IV) animal age (data from Veiseth et al., 2004); (V) species (data from Koohmaraie et al., 1991a); and (VI) breeds (data from Whipple et al., 1990b).

study clearly showed that postmortem proteolysis was largely inhibited in $\mu$-calpain knockout mice (Fig. 4). The limited proteolysis that did occur could be attributed to m-calpain, which is activated, as evidenced by autolysis, to some extent in postmortem murine skeletal muscle, contrary to what occurs with m-calpain in the muscles of meat-producing animals (Geesink et al., 2006; Kent et al., 2004).

\section{Where do we go from here?}

As stated previously, tenderness is the most important eating quality factor affecting consumer satisfaction. Thus, biological and other factors that determine meat tenderness have been the subject of intense research for almost a century. We have learned that essentially three factors can account for the great majority of the observed variation in meat tenderness, and they are proteolysis, connective tissue and sarcomere length (Rhee, Wheeler, Shackelford, \& Koohmaraie, 2004; Wheeler et al., 2000b). The relative importance of proteolysis, connective tissue and sarcomere length to tenderness is muscle dependent (e.g., while proteolysis is the major determinant of longissimus tenderness, sarcomere length is the major determinant of psoas major tenderness). There are a number of muscles for which all three factors contribute to the tenderness of these muscles. 


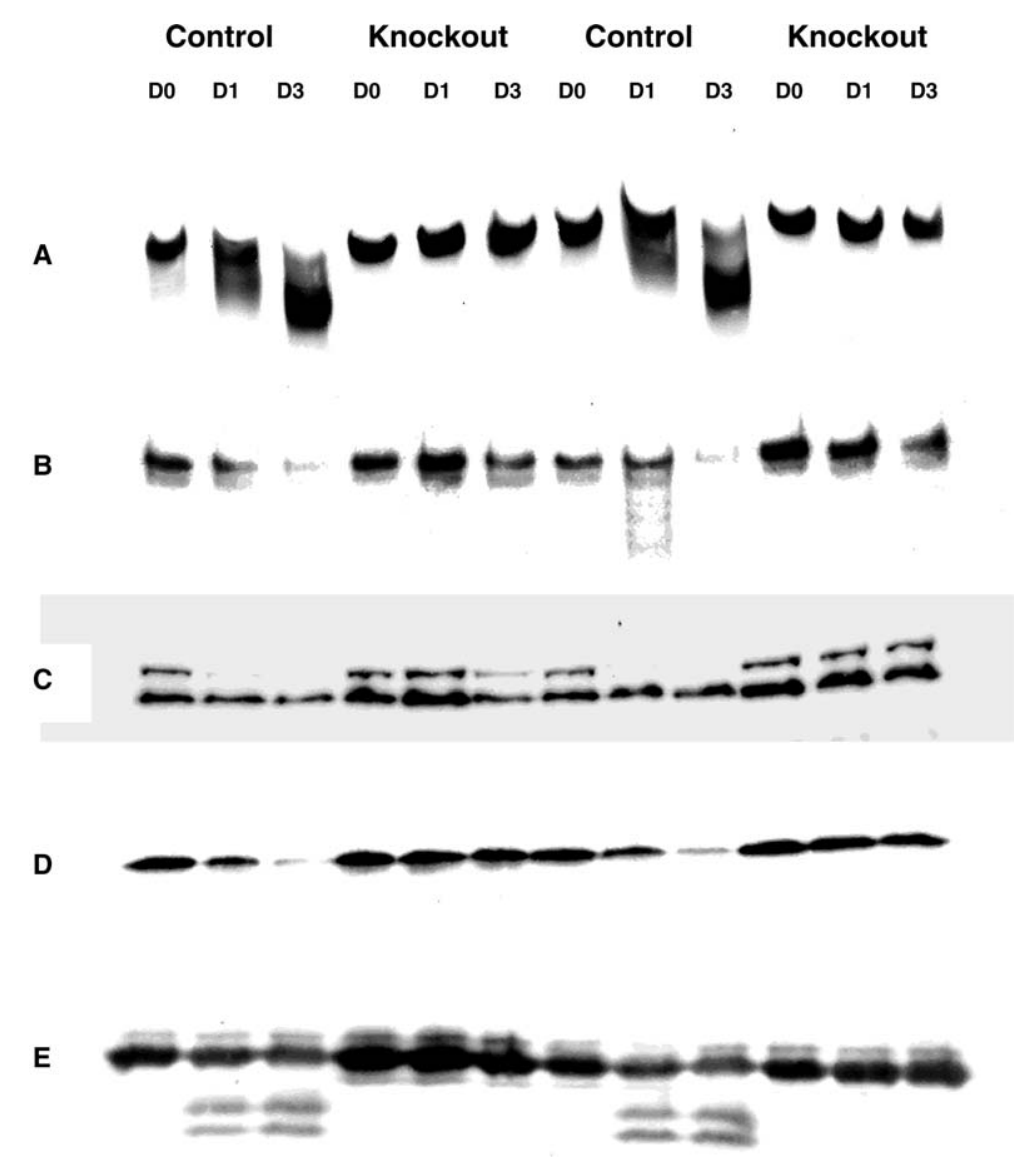

Fig. 4. Western blot analysis of nebulin (A), dystrophin (B), metavinculin and vinculin (C), desmin (D), and troponin-T (E) in whole muscle extracts of two control and two $\mu$-calpain knockout mice at death (D0) and after 1 (D1) and 3 days' (D3) storage at $4{ }^{\circ} \mathrm{C}$ (from Geesink et al., 2006).

We, at the US Meat Animal Research Center, have tended to focus our efforts on determining the basis for tenderness of longissimus muscle, primarily due to its economic significance.

Because of the importance of tenderness, significant attempts have been made to ensure the tenderness of longissimus when presented to the consumer. Due to our inability to predict longissimus tenderness until very recently, one does not really know the degree of tenderness until the meat is eaten. The level of uncertainty is simply unacceptable and has led to efforts to develop methods to predict tenderness. Processing conditions and the time elapsed from exsanguination to meat on the plate varies throughout the world based on tradition, custom and culture. To the extent possible, it is the responsibility of researchers to enable industry to provide consumers with palatable meat regardless of variation in practices in various countries. As a result of decades of research, the meat industry in the United States (and undoubtedly in other countries) is well educated with respect to the importance of postmortem storage (5-7 days for pork, 7-10 days for lamb and 14 days for beef) to the ultimate tenderness. In the United States, 36-48 h after exsanguination carcasses are graded for quality (based on intramuscular fat or marbling) and yield. Any tenderness prediction will more than likely be done along with quality and yield grading. It is well established that the variation in the rate and extent of postmortem proteolysis and tenderization is the source of the variation in meat tenderness at the consumer level. Because of the variation in the rate of postmortem proteolysis, any prediction method will have to be able to predict the potential of a muscle to undergo postmortem proteolysis from the time of prediction until 14 days of postmortem storage. Because of the difficulty in developing an instrument that can predict tenderization that occurs beyond 36-48 h (the time at which tenderness will be predicted), there is no accurate method of predicting tenderness. It is highly likely that we can develop methods that can predict meat tenderness at the time of measurement. Therefore, if we could accelerate postmortem proteolysis so that much of it has happened by the time of tenderness prediction (36-48 $\mathrm{h}$ post exsanguination in the United States), the likelihood of developing a tenderness prediction method would dramatically increase.

We hope that the data presented in this review paper and in the original papers that are the basis for this review paper will once and for all convince the researchers in this field that postmortem tenderization is due to $\mu$-calpaininduced degradation of key myofibrillar proteins. Acceptance of such a conclusion, which is rooted in sound 
research, will enable the researchers to focus their efforts to elucidate the regulation of $\mu$-calpain in postmortem muscle. If application of knowledge of $\mu$-calpain regulation results in acceleration of $\mu$-calpain activity, it should facilitate the development of accurate methods of predicting meat tenderness and ultimately in methods to ensure all meat is acceptably tender.

\section{Conclusions}

Data generated by numerous projects in our laboratory, as well as in laboratories around the world, have convinced us that $\mu$-calpain-induced degradation of key myofibrillar proteins is the cause of postmortem proteolysis and, hence, $\mu$-calpain activity is the primary source of variation in tenderness of muscles for which proteolysis is the major determinant of tenderness. Discovering the mechanisms of $\mu$-calpain activity regulation in early postmortem muscle and, more importantly, the development of methods to accelerate $\mu$-calpain activity within the constraints of highly regulated production practices should have a dramatic effect on the ability of the meat industry to produce a product that is consistently tender.

\section{References}

Abbot, M. T., Pearson, A. M., Price, J. F., \& Hooper, G. R. (1977). Ultrastructural changes during autolysis of red and white porcine muscle. Journal of Food Science, 42, 1185-1188.

Anderson, L. V. B., Davison, K., Moss, J. A., Richard, I., Fardeau, M., Tomé, F. M. S., et al. (1998). Characterization of monoclonal antibodies to calpain 3 and protein expression in muscle from patients with limb-girdle muscular dystrophy type 2A. American Journal of Pathology, 153, 1169-1179.

Belk, K. E., Scanga, J. A., Wyle, A. M., Wulf, D. M., Tatum, J. D., Reagan, J. O., et al. (2000). The use of video image analysis and instrumentation to predict beef palatability. In Proceedings of the $53 \mathrm{rd}$ annual reciprocal meat conference, Ohio, USA (pp. 10-15).

Bickerstaffe, R., Bekhit, A. E. D., Robertson, L. J., Roberts, N., \& Geesink, G. H. (2001). Impact of introducing specifications on the tenderness of retail meat. Meat Science, 59, 303-315.

Boleman, S. J., Boleman, S. L., Miller, R. K., Taylor, J. F., Cross, H. R., Wheeler, T. L., et al. (1997). Consumer evaluation of beef of known categories of tenderness. Journal of Animal Science, 75, 15211524.

Bouton, P. E., Harris, P. V., Shorthose, W. R., \& Baxter, R. I. (1973). A comparison of the effects of aging, conditioning and skeletal restraint on the tenderness of mutton. Journal of Food Science, 38, 932-937.

Brown, N., \& Crawford, C. (1993). Structural modifications associated with the change in $\mathrm{Ca}^{2+}$ sensitivity on activation of m-calpain. FEBS Letters, 322, 65-68.

Byrne, C. E., Downey, G., Troy, D., \& Buckley, D. (1998). Nondestructive prediction of selected quality attributes of beef by nearinfrared reflectance spectroscopy. Meat Science, 49, 399-409.

Cottin, P., Vidalenc, P. L., \& Ducastaing, A. (1981). $\mathrm{Ca}^{2+}$-dependent association between a $\mathrm{Ca}^{2+}$-activated neutral proteinase (CaANP) and its specific inhibitor. FEBS Letters, 136, 221-224.

Davey, C. L., \& Dickson, D. R. (1970). Studies in meat tenderness 8. Ultrastructural changes in meat during aging. Journal of Food Science, $35,56-60$.

Davey, C. L., \& Gilbert, K. V. (1969). Studies of meat tenderness. 7 Changes in the fine structure of meat during aging. Journal of Food Science, 34, 69-74.
Dayton, W. R. (1982). Comparison of low- and high-calcium-requiring forms of the calcium-activated protease with their autolytic breakdown products. Biochimica et Biophysica Acta, 709, 166-172.

Dayton, W. R., Goll, D. E., Zeece, M. G., Robson, R. M., \& Reville, W. (1976). A Ca ${ }^{2+}$-activated protease possibly involved in myofibrillar protein turnover. Purification from porcine muscle. Biochemistry, 15, $2150-2158$

Dayton, W. R., Reville, W. J., Goll, D. E., \& Stromer, M. H. (1976). A $\mathrm{Ca}^{2+}$-activated protease possibly involved in myofibrillar protein turnover. Partial characterization of the purified enzyme. Biochemistry, $15,2159-2167$.

Dayton, W. R., Schollmeyer, J. V., Lepley, R. A., \& Cortés, L. R. (1981). A calcium-activated protease possibly involved in myofibrillar protein turnover. Isolation of a low-calcium-requiring form of the protease. Biochimica et Biophysica Acta, 659, 48-61.

DeMartino, G. N., Wachendorfer, R., McGuire, M., \& Croall, D. E. (1988). Proteolysis of the protein inhibitor of calcium-dependent proteases produces lower molecular weight fragments that retain inhibitory activity. Archives of Biochemistry and Biophysics, 262, 189-198.

Doumit, M. E., \& Koohmaraie, M. (1999). Immunoblot analysis of calpastatin degradation: evidence for cleavage by calpain in postmortem muscle. Journal of Animal Science, 77, 1467-1473.

Ducastaing, A., Valin, C., Schollmeyer \& Cross, R. (1985). Effects of electrical stimulation on post-mortem changes in the activities of two $\mathrm{Ca}$ dependent neutral proteinases and their inhibitor in beef muscle. Meat Science, 15, 193-202.

Dutson, T. R., Pearson, A. M., \& Merkel, R. A. (1974). Ultrastructural postmortem changes in normal and low quality porcine muscle fibers. Journal of Food Science, 39, 32-37.

Emori, Y., Kawasaki, H., Imajoh, S., Kawashima, S., \& Suzuki, K. (1986). Isolation and sequence analysis of cDNA clones for the small subunit of rabbit calcium-dependent protease. Journal of Biological Chemistry, 261, 9472-9476.

Feldkamp, T. J., Schroeder, T. C., \& Lusk, J. L. (2005). Determining consumer valuation of differentiated beef steak quality attributes. Journal of Muscle Foods, 16, 1-15.

Garssen, G. J., Geesink, G. H., Hoving-Bolink, A. H., \& Verplanke, J. C. (1995). Effects of dietary clenbuterol and salbutamol on meat quality in veal calves. Meat Science, 40, 337-350.

Geesink, G. H., \& Koohmaraie, M. (1999a). Effect of calpastatin on degradation of myofibrillar proteins by $\mu$-calpain under postmortem conditions. Journal of Animal Science, 77, 2685-2692.

Geesink, G. H., \& Koohmaraie, M. (1999b). Postmortem proteolysis and calpain/calpastatin activity in callipyge and normal lamb biceps femoris during extended postmortem storage. Journal of Animal Science, 77, 1490-1501.

Geesink, G. H., Kuchay, S., Chishti, A. H., \& Koohmaraie, M. (2006). $\mu$-Calpain is essential for postmortem proteolysis of muscle proteins. Journal of Animal Science, in press.

Geesink, G. H., Taylor, R. G., \& Koohmaraie, M. (2005). Calpain 3/p94 is not involved in postmortem proteolysis. Journal of Animal Science, $83,1646-1652$.

George, M. H., Tatum, J. D., Belk, K. E., \& Smith, G. C. (1999). An audit of retail beef loin steak tenderness conducted in eight US cities. Journal of Animal Science, 77, 1735-1741.

Goll, D. E., Otsuka, Y., Nagainis, P. A., Shannon, J. D., Sathe, S. K., \& Muguruma, M. (1983). Role of muscle proteinases in maintenance of muscle integrity and mass. Journal of Food Biochemistry, 7, 137-177.

Goll, D. E., Thompson, V. F., Li, H., Wei, W., \& Cong, J. (2003). The calpain system. Physiological Reviews, 83, 731-801.

Herring, H. K., Cassens, R. G., Suess, G. G., Brungardt, V. H., \& Briskey, E. J. (1967). Tenderness and associated characteristics of stretched and contracted bovine muscles. Journal of Food Science, 32, 317-323.

Ho, C. Y., Stromer, M. H., Rouse, G., \& Robson, R. M. (1996). Effect of electrical stimulation on postmortem titin, nebulin, desmin, troponin-T degradation and ultrastructural changes in bovine longissimus muscle. Journal of Animal Science, 74, 1563-1575. 
Hoagland, R., McBryde, C. N., \& Powick, W. C. (1917). Changes in fresh beef during cold storage above freezing. United States Department of Agriculture Bulletin, 433, 1-100.

Huff-Lonergan, E., Mitsuhashi, M., Beekman, D. D., Parrish, F. C., Jr., Olson, D. G., \& Robson, R. M. (1996). Proteolysis of specific muscle structural proteins by $\mu$-calpain at low $\mathrm{pH}$ and temperature is similar to degradation in postmortem bovine muscle. Journal of Animal Science, 74, 993-1008.

Huffman, K. L., Miller, M. F., Hoover, L. C., Wu, C. K., Brittin, H. C., \& Ramsey, C. B. (1996). Effect of beef tenderness on consumer satisfaction with steaks consumed in the home and restaurant. Journal of Animal Science, 74, 91-97.

Ilian, M. A., Bekhit, A. E. D., \& Bickerstaffe, R. (2004). The relationship between meat tenderization, myofibril fragmentation and autolysis of calpain 3 during post-mortem aging. Meat Science, 66, 387397.

Imajoh, S., \& Suzuki, K. (1985). Reversible interaction between $\mathrm{Ca}^{2+}$ activated neutral protease (CANP) and its endogenous inhibitor. FEBS Letters, 187, 47-50.

Inomata, M., Kasai, Y., Nakamura, M., \& Kawashima, S. (1988). Activation mechanism of calcium activated neutral protease. Journal of Biological Chemistry, 263, 19783-19787.

Kent, M. P., Spencer, M. J., \& Koohmaraie, M. (2004). Postmortem proteolysis is reduced in transgenic mice overexpressing calpastatin. Journal of Animal Science, 82, 794-801.

Koohmaraie, M. (1988). The role of endogenous proteases in meat tenderness. In Proceedings of 41 st annual reciprocal meat conference, Wyoming, USA (pp. 89-100).

Koohmaraie, M. (1990). Inhibition of postmortem tenderization in ovine carcasses through infusion of zinc. Journal of Animal Science, 68, 1476-1483.

Koohmaraie, M. (1992). Ovine skeletal muscle multicatalytic proteinase complex (proteasome): purification, characterization, and comparison of its effect on myofibrils with $\mu$-calpain. Journal of Animal Science, 70, 3697-3708

Koohmaraie, M., Babiker, A. S., Schroeder, A. L., Merkel, R. A., \& Dutson, T. R. (1988). Acceleration of postmortem tenderization in ovine carcasses through activation of $\mathrm{Ca}^{2+}$-dependent proteases. Journal of Food Science, 53, 1638-1641.

Koohmaraie, M., Doumit, M. E., \& Wheeler, T. L. (1996). Meat toughening does not occur when rigor shortening is prevented. Journal of Animal Science, 74, 2935-2942.

Koohmaraie, M., Schollmeyer, J. E., \& Dutson, T. R. (1986). Effect of low-calcium-requiring calcium activated factor on myofibrils under varying $\mathrm{pH}$ and temperature conditions. Journal of Food Science, 51, $28-32$.

Koohmaraie, M., Seideman, S. C., Schollmeyer, J. E., Dutson, T. R., \& Crouse, J. D. (1987). Effects of post-mortem storage on $\mathrm{Ca}^{++}$dependent proteases, their inhibitor and myofibril fragmentation. Meat Science, 19, 187-196.

Koohmaraie, M., Shackelford, S. D., Muggli-Cockett, N. E., \& Stone, R. T. (1991b). Effect of the $\beta$-adrenergic agonist $\mathrm{L}_{644,969}$ on muscle growth, endogenous proteinase activities, and postmortem proteolysis in wether lambs. Journal of Animal Science, 69, 4823-4835.

Koohmaraie, M., Shackelford, S. D., Wheeler, T. L., Lonergan, S. N., \& Doumit, M. E. (1995). A muscle hypertrophy condition in lamb (callipyge): characterization of effects on muscle growth and meat quality traits. Journal of Animal Science, 73, 3596-3607.

Koohmaraie, M., Whipple, G., \& Crouse, J. D. (1990). Acceleration of postmortem tenderization in lamb and Brahman-cross beef carcasses through infusion of calcium chloride. Journal of Animal Science, 68, $1278-1283$.

Koohmaraie, M., Whipple, G., Kretchmar, D. H., Crouse, J. D., \& Mersmann, H. J. (1991a). Postmortem proteolysis in longissimus muscle from beef, lamb and pork carcasses. Journal of Animal Science, 69, 617-624.

Kretchmar, D. H., Hathaway, M. R., Epley, R. J., \& Dayton, W. R. (1990). Alterations in postmortem degradation of myofibrillar proteins in lamb fed a $\beta$-adrenergic agonist. Journal of Animal Science, 68 , $1760-1772$.

Lee, W. J., Ma, H., Takano, E., Yang, H. Q., Hatanaka, M., \& Maki, M. (1992). Molecular diversity in amino-terminal domains of human calpastatin by exon skipping. Journal of Biological Chemistry, 267, 8437-8442.

Li, J., \& Shatadal, P. (2001). Classification of tough and tender beef by image texture analysis. Meat Science, 57, 341-346.

Locker, R. H. (1960). Degree of muscle contraction as a factor in tenderness of beef. Food Research, 25, 304-307.

Lusk, J. L., Fox, J. A., Schroeder, T. C., Mintert, J., \& Koohmaraie, M. (2001). In-store valuation of steak tenderness. American Journal of Agricultural Economics, 83, 539-550.

Maki, M., Takano, E., Osawa, T., Ooi, T., Murachi, T., \& Hatanaka, M. (1988). Analysis of structure-function relationship of pig calpastatin by expression of mutated cDNAs in Escherichia coli. Journal of Biological Chemistry, 263, 10254-10261.

Marsh, B. B., \& Leet, N. G. (1966). Studies in meat tenderness. III. The effects of cold shortening on tenderness. Journal of Food Science, 31, 450-459.

Mellgren, R. L., Mericle, M. T., \& Lane, R. D. (1986). Proteolysis of the calcium-dependent protease inhibitor by myocardial calcium-dependent protease. Archives of Biochemistry and Biophysics, 246, 233-239.

Miller, M. F., Carr, M. F., Ramsey, C. B., Crockett, K. L., \& Hoover, L. C. (2001). Consumer thresholds for establishing the value of beef tenderness. Journal of Animal Science, 79, 3062-3068.

Morgan, J. B., Savell, J. W., Hale, D. S., Miller, R. K., Griffin, D. B., Cross, H. R., et al. (1991). National beef tenderness survey. Journal of Animal Science, 69, 3274-3283.

Nagainis, P. A., Sathe, S. K., Goll, D. E., \& Edmunds, T. (1983). Autolysis of high- $\mathrm{Ca}^{2+}$ and low $\mathrm{Ca}^{2+}$-forms of the $\mathrm{Ca}^{2+}$-dependent proteinase from bovine skeletal muscle. Federation Proceedings, 42, 1780.

Nakamura, M., Inomata, M., Imajoh, S., Suzuki, K., \& Kawashima, S. (1989). Fragmentation of an endogenous inhibitor upon complex formation with high- and low- $\mathrm{Ca}^{2+}$-requiring forms of calciumactivated neutral proteases. Biochemistry, 28, 449-455.

Olson, D. G., Parrish, F. C., Dayton, W. R., \& Goll, D. E. (1977). Effect of postmortem storage and calcium activated factor on the myofibrillar proteins of bovine skeletal muscle. Journal of Food Science, 42, $117-124$

Ouali, A., \& Talmant, A. (1990). Calpains and calpastatin distribution in bovine, porcine and ovine skeletal muscles. Meat Science, 28, 331-348.

Park, B., Chen, Y. R., Hruschka, W. R., Shackelford, S. D., \& Koohmaraie, M. (1998). Near-infrared reflectance analysis for predicting beef longissimus tenderness. Journal of Animal Science, 76, 2115-2120.

Parr, T., Sensky, P. L., Scothern, G. P., Bardsley, R. G., Buttery, P. J., Wood, J. D., et al. (1999). Relationship between skeletal musclespecific calpain, p94/calpain 3. Journal of Animal Science, 77, 661-668.

Polkinghorne, R., Watson, R., Porter, M., Gee, A., Scott, J., \& Thompson, J. (1999). The use of consumer scores to set grade standards. In Proceedings of the 45th international conference of meat science and technology, Yokohama, Japan (pp. 14-15).

Rhee, M. S., Wheeler, T. L., Shackelford, S. D., \& Koohmaraie, M. (2004). Variation in palatability and biochemical traits within and among eleven beef muscles. Journal of Animal Science, 82, 534-550.

Robson, R. M., Huff-Lonergan, E., Parrish, F. C., Ho, C. Y., Stromer, M. H., Huiatt, T. W., et al. (1997). Postmortem changes in the myofibrillar and cytoskeletal proteins in muscle. In Proceedings of the 50th annual reciprocal meat conference, Iowa, USA (pp. 43-52).

Savell, J. W., Shackelford, S. D. (1992). Significance of tenderness to the meat industry. In Proceedings of 45th annual reciprocal meat conference, Colorado, USA (pp. 43-46).

Shackelford, S. D., Koohmaraie, M., Miller, M. F., Crouse, J. D., \& Reagan, J. O. (1991). An evaluation of tenderness of the longissimus muscle of Angus by Hereford versus Brahman crossbred heifers. Journal of Animal Science, 69, 171-177. 
Shackelford, S. D., Wheeler, T. L., \& Koohmaraie, M. (2004). Development of optimal protocol for visible and near-infrared reflectance spectroscopic evaluation of meat quality. Meat Sci., 68, 371-381.

Shackelford, S. D., Wheeler, T. L., \& Koohmaraie, M. (2005). On-line classification of US select beef carcasses for longissimus tenderness using visible and near-infrared reflectance spectroscopy. Meat Sci., 69, $409-415$.

Shackelford, S. D., Wheeler, T. L., \& Koohmaraie, M. (1999). Tenderness classification of beef: II. Design and analysis of a system to measure beef longissimus shear force under commercial processing conditions. Journal of Animal Science, 77, 1474-1481.

Shackelford, S. D., Wheeler, T. L., Meade, M. K., Reagan, J. O., Byrnes, B. L., \& Koohmaraie, M. (2001). Consumer impressions of Tender Select beef. Journal of Animal Science, 79, 2605-2614.

Smith, G. C., Savell, J. W., Dolezal, H. G., Field, T. G., Gill, D. R., Griffin, D. B., et al. (1995). Improving the quality, consistency, competetiveness and marketshare of beef: the final report of the second blueprint for total quality management in the fed-beef (slaughter steer/ heifer) industry. National Beef Quality Audit-1995.

Sorimachi, H., Ishiura, S., \& Suzuki, K. (1989). Molecular cloning of a novel mammalian calcium dependent protease distinct from both $\mathrm{m}-$ and $\mu$-types. Journal of Biological Chemistry, 264, 20106-20111.

Sorimachi, H., Kinbara, K., Kimura, S., Takahashi, M., Ishiura, S., Sasagawa, N., et al. (1995). Muscle-specific calpain, p94, responsible for limb girdle muscular dystrophy type $2 \mathrm{~A}$, associates with connectin through IS2, a p94-specific sequence. Journal of Biological Chemistry, $270,31158-31162$.

Sorimachi, H., Toyama-Sorimachi, N., Saido, T. C., Kawasaki, H., Sugita, H., Miyasaka, M., et al. (1993). Muscle-specific calpain, p94, is degraded by autolysis immediately after translation, resulting in disappearance from muscle. Journal of Biological Chemistry, 268, 10593-10605.

Strandine, E. J., Koonz, C. H., \& Ramsbottom, J. M. (1949). A study of variations in muscles of beef and chicken. Journal of Animal Science, 8 , 483-494.

Suzuki, K., Tsuji, S., Ishiura, S., Kimura, Y., Kubota, S., \& Imahori, K. (1981). Autolysis of calcium-activated neutral protease of chicken skeletal muscle. Journal of Biochemistry, 90, 1787-1793.

Suzuki, K., Tsuji, S., Kubota, S., Kimura, Y., \& Imahori, K. (1981). Limited autolysis of $\mathrm{Ca}^{2+}$-activated neutral protease (CANP) changes its sensitivity to $\mathrm{Ca}^{2+}$ ions. Journal of Biochemistry, 90, 275-278.

Taylor, R. G., \& Koohmaraie, M. (1998). Effects of postmortem storage on the ultrastructure of the endomysium and myofibrils in normal and callipyge longissimus. Journal of Animal Science, 76, 2811-2817.

Taylor, R. G., Geesink, G. H., Thompson, V. F., Koohmaraie, M., \& Goll, D. E. (1995a). Is Z-disk degradation responsible for postmortem tenderization? Journal of Animal Science, 21, 1351-1367.

Taylor, R. G., Tassy, C., Briand, M., Robert, N., Briand, Y., \& Ouali, A. (1995b). Proteolytic activity of proteasome on myofibrillar structures. Molecular Biology Reports, 21, 71-73.

Thompson, J. R., Polkinghorne, R., Watson, R., Gee, A., \& Murrison, B. (1999). A cut based grading scheme to predict eating quality by cooking method. In Proceedings of the 45th international conference of meat science and technology, Yokohama, Japan (pp. 20-21).

Uytterhaegen, L., Claeys, E., \& Demeyer, D. (1994). Effects of exogenous protease effectors on beef tenderness and myofibrillar degradation and solubility. Journal of Animal Science, 72, 1209-1223.
Veiseth, E., Shackelford, S. D., Wheeler, T. L., \& Koohmaraie, M. (2001). Effect of post-mortem storage on $\mu$-calpain and m-calpain in ovine skeletal muscle. Journal of Animal Science, 70, 3035-3043.

Veiseth, E., Shackelford, S. D., Wheeler, T. L., \& Koohmaraie, M. (2004). Factors regulating lamb longissimus tenderness are affected by age at slaughter. Meat Science, 68, 635-640.

Vote, D. J., Belk, K. E., Tatum, J. D., Scanga, J. A., \& Smith, G. C. (2003). Online prediction of beef tenderness using a computer vision system equipped with a BeefCam module. Journal of Animal Science, 81, 457-465.

Wheeler, T. L., Crouse, J. D., \& Koohmaraie, M. (1992). The effect of postmortem time of injection and freezing on the effectiveness of calcium chloride for improving beef tenderness. Journal of Animal Science, 70, 3451-3457.

Wheeler, T. L., Cundiff, L. V., \& Koch, R. M. (1994). Effect of marbling degree on beef palatability in Bos taurus and Bos indicus cattle. Journal of Animal Science, 72, 3145-3151.

Wheeler, T. L., \& Koohmaraie, M. (1994). Prerigor and postrigor changes in tenderness of ovine longissimus muscle. Journal of Animal Science, $72,1232-1238$

Wheeler, T. L., \& Koohmaraie, M. (1999). The extent of proteolysis is independent of sarcomere length in lamb longissimus and psoas major. Journal of Animal Science, 77, 2444-2451.

Wheeler, T. L., Koohmaraie, M., \& Crouse, J. D. (1991). Effects of calcium chloride injection and hot boning on the tenderness of round muscles. Journal of Animal Science, 78, 958-965.

Wheeler, T. L., Shackelford, S. D., \& Koohmaraie, M. (1999). MARC classification system: objective evaluation of beef tenderness and cutability. Bulletin. Clay Center, NE: Roman L. Hruska US Meat Animal Research Center, Agricultural Research Service, US Department of Agriculture.

Wheeler, T. L., Shackelford, S. D., \& Koohmaraie, M. (2000a). Relationship of beef longissimus tenderness classes to tenderness of gluteus medius, semimembranosus, and biceps femoris. Journal of Animal Science, 78, 2856-2861.

Wheeler, T. L., Shackelford, S. D., \& Koohmaraie, M. (2000b). Variation in proteolysis, sarcomere length, collagen content, and tenderness among major pork muscles. Journal of Animal Science, 78, 958965.

Wheeler, T. L., Vote, D., Leheska, J. M., Shackelford, S. D., Belk, K. E., Wulf, D. M., et al. (2002). The efficacy of three objective systems for identifying beef cuts that can be guaranteed tender. Journal of Animal Science, 80, 3315-3327.

Whipple, G., Koohmaraie, M., Dikeman, M. E., \& Crouse, J. D. (1990a). Predicting beef-longissimus tenderness from various biochemical and histological muscle traits. Journal of Animal Science, 68, 41934199.

Whipple, G., Koohmaraie, M., Dikeman, M. E., Crouse, J. D., Hunt, M. C., \& Klemm, R. D. (1990b). Evaluation of attributes that affect longissimus muscle tenderness in Bos taurus and Bos indicus cattle. Journal of Animal Science, 68, 2716-2728.

Wulf, D. M., \& Page, J. K. (2000). Using measurements of muscle color, $\mathrm{pH}$, and electrical impedance to augment the current USDA beef quality grading standard and improve the accuracy and precision of sorting carcasses into palatability groups. Journal of Animal Science, $78,2595-2607$. 